\title{
The Pros and Cons of the "New Normal" Concept during COVID-19 Outbreak
}

\author{
Nadi Suprapto', Akhmad Zamroni' ${ }^{2}$, Azmil Abidah ${ }^{3}$, Desi Wulandari4 \\ 1Physics Education Program, Universitas Negeri Surabaya, Surabaya, Indonesia \\ 2Department of Geological Engineering, Institut Teknologi Nasional Yogyakarta, \\ Yogyakarta, Indonesia \\ ${ }^{3}$ Pharmacy High School of Sekesal, Surabaya, Indonesia \\ ${ }^{4}$ Postgraduate Program of Science Education, Universitas Negeri Surabaya, \\ Surabaya, Indonesia \\ nadisuprapto@unesa.ac.id,akhmadzamroni@itny.ac.id,azmil.abidah@gmail.com \\ desiwulan770@gmail.com
}

\begin{tabular}{ll}
\hline Article History & Received : January $7^{\text {th }} 2021$ \\
& Revision : February $11^{\text {th }} 2021$ \\
& Publication : March $30^{\text {th }} 2021$ \\
\hline
\end{tabular}

\begin{abstract}
This paper narrates how the author's position based on the hot issue of nurturing the COVID-19 pandemic. The pros and cons of the "New Normal" concept [kenormalan baru] are argumentatively illustrated through a literature search. The primer information from WHO, policymaker, and researchers contributed to the discussion. Health protocols become the rules mentioned in implementing a new normal, namely by reducing physical contact with others. Nevertheless, the new normal policy is no less low and dangerous, is the insufficient appreciation of science, especially revelation. Thus, the concept of the new normal has not valued except just taking material and economic benefits.
\end{abstract}

Keywords: COVID-19, New Normal, Pandemic.

\section{INTRODUCTION}

The WHO "new normal" is echoed amid the coronavirus pandemic, which is increasingly widespread and infecting millions of people globally, including in Indonesia. The Indonesian government also invited the people to be able to live in peace with COVID-19. As a result of this pandemic, the world community was forced to stay at home. We agree that work, school, to worship must also be done at home, except for those who have to move outside. This extreme change has had a huge impact on people's lives and in many sectors. Since the new Coronavirus, SARS-CoV2 , which is endemic from China, continues to spread, until now, the drugs and vaccines that cause COVID-19 disease are still being developed. 
Many countries try to apply the WHO new normal as an effort to co-exist with the Coronavirus. However, many new normal provisions should be considered so that the number of cases does not surge. The concept of new normal life later became viral and was discussed in Indonesia and throughout the world. This concept is not only applied in this country because it is a concept of the WHO as a world health agency (Carr, 2020).

Since the outbreak of the Coronavirus, the UN health agency has designated it a COVID-19 pandemic worldwide. The number of people exposed had reached more than 5 million people worldwide (covid19.go.id.). In the new WHO normal concept, life activities will be returned to the conditions before COVID-19 (Chen et al., 2020; WHO, 2020). That is why many countries are interested and want to apply this concept by loosening the lockdown rules. The lockdown policy or the area quarantine has caused various aspects of life to be affected. In addition to many people who have lost their jobs and have difficulty eating, staying at home also has an equally severe psychological impact.

Indonesia itself has implemented "Pembatasan Sosial Berskala Besar" (PSBB) or Large-Scale Social Restrictions to prevent the spread of the Coronavirus. Office and business activities were stopped; the community was prohibited from gathering. However, many countries implementing the new WHO normal concept cannot be done simply by loosening physical distancing. The following are some of the provisions that WHO requires, as quoted from its official page (WHO, 2020).

1. Countries that will implement the new normal concept must have proof that the transmission of COVID-19 in its territory has been controlled.

2. Existing health systems, from hospitals to medical equipment, are able to identify, isolate, test, track contacts, and quarantine infected people.

3. The risk of Coronavirus outbreaks must be suppressed for areas or places with high vulnerability, primarily for older people's homes, mental health facilities, and dense residential areas.

4. For the implementation of new WHO in the work environment, prevention measures are determined through the application of physical distancing, hand washing facilities, and respiratory ethics (with masks).

5. Risk of cases from virus carriers entering a region must be controlled.

6. The public must be given the opportunity to provide input, opinion, and be involved in the transition process of the WHO's new normal concept.

Before easing restrictions, we need to make sure those criteria are applied. If we cannot, we should think again. The world immediately welcomes initiatives to relax rules through the new WHO concept. Several countries have begun to loosen lockdowns, such as Spain, Italy, and the UK, which have the highest number of Europe cases. Office activities, business activities, and many schools have begun to 
reopen. The United States, the country with the highest number of COVID-19 cases globally, also plans to end the lockdown soon (Djalante et al., 2020).

Specifically, Indonesia has an 'Indonesian version of WHO New Normal'. The Indonesian government also plans to implement the concept after the Indonesian President stated the need for people to enter a new normal life side by side with the Coronavirus. Although social restrictions are relaxed, new life will continue to prioritize strict health protocols (Chen et al., 2020). Both in the activities at the office, shopping, eating, to worship.

Even though various groups have criticized the concept of the Indonesian version of the WHO new normal, the impact of social restrictions is no less destructive. That is why this application will be successful if followed by increased awareness of the community. This paper proposes its position regarding the concept of the new normal. It also provides some dialogue in relating to the pros and cons of the new normal concept.

\section{METHOD}

This paper adopted the philosophy of the position paper (Abidah et al., 2020). The paper's exposition utilizes six primary components of the Toulmin Argument Pattern in performing the discussion: data (evidence), qualifier, claim, warrant, backing, and rebuttal (Erduran, Jiménez-Aleixandre, \& Pilar, 2007). The previous researcher used the term a conceptual analysis (see Razzak, 2020). A position paper attempts to reassure the reader that our perspective is accurate and defensible (Abidah et al., 2020; Suprapto, 2016; Suprapto et al., 2017). Generally, the steps in writing a position paper included: "(1) Select a topic for our paper; (2) Conduct preliminary research; (3) Challenge our topic; (4) Continue to collect supporting evidence; and (5) Create an outline" (Belliappa, 2020; Fleming, 2020). The study was also part of a spontaneous study based on the world's trending issue, such as the COVID-19 pandemic. Therefore, to support the ideas and argument, the voice, the opinion, and the public figure's argument, a government representative, a politician was depicted.

\section{RESULTS AND DISCUSSION}

In the New Normal, the four main problems are globalization and trade, technology (Meiryani et al., 2020), and innovation (Clark, 2020), societal impacts, and behavioral shifts (Indartono et al., 2020). Shifting trade from cash transactions to digital transactions is the main characteristic of the first issue. Several star-ups have appeared in Indonesia, for example, Gojek, Tokopedia, Traveloka, Akulaku, etc. 
The paradigm of now-next-beyond of COVID-19 in the business sector is alternative guidance (Figure 1).

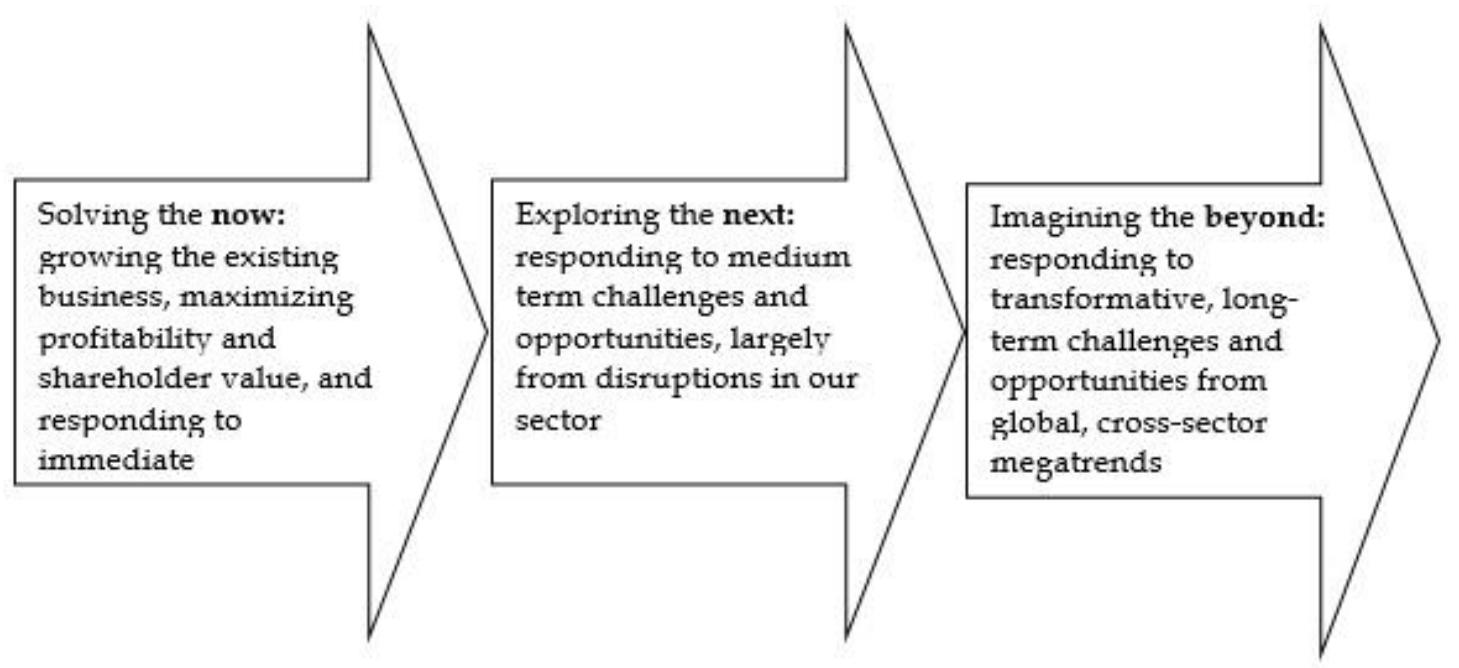

Figure 1 - The paradigm of now-next-beyond of COVID-19

Meanwhile, several innovations emerged during the COVID-19 pandemic: Virtual Music Concert, virtual sports, Go Subscription, AI for Physical Distancing, and Virtual Tourism (Clark, 2020; Benjamin et al., 2020). At present, all forms of media services such as writing, audio, and video will lead to a subscription business model. This significant jump occurred because COVID-19 encouraged young and old consumers to be greedier for digital content. The development of digital innovation provides retail companies solutions when they have to maintain their in-store income while providing security guarantees due to the COVID-19 attacks (Clark, 2020). The tourism sector was devastated by the presence of COVID-19. All tourist destinations are closed and empty because of social distancing (Benjamin et al., 2020). The role of technological innovation has dramatically helped tourism to survive the crisis (Republika, 2020).

COVID-19 gives societal impacts. People began to be afraid to interact, so that many social, economic, and religious activities that were massive and physical stopped. Even the outbreak of COVID-19 complicates the threat of an economic downturn. Hotels, tourist attractions, quiet. Freelancers have much confusion because of lost income.

One interesting phenomenon has become a trend due to the corona, employees, begin their office work activities at home or known as WFH (Work from Home). Leaders and employees are starting to infatuate using video conferencing (vicon) and interacting socially and economically online. Initially, many employees grumbled and were clumsy with the WFH policy, although this was normal in behavior change. Nevertheless, lately, both government and private offices have 
become accustomed to digital work, vicon, e-learning, and other activities that involve many people at home.

Job applications, attendance, job reports, interact online-most of the work activities passing by in the internet world, without presenting physical human. Very frugal, the hustle and bustle of road congestion are greatly reduced, office operational costs such as the use of air conditioning, electricity, water, etc., are also clearly reduced. Moreover, in time, we will become more accustomed to working at home by optimizing digital facilities, which have long offered convenience. Indeed, this cultural change must be immediately utilized by policymakers to build organizational systems and new work systems, which are genuinely digital-based.

A hierarchical organizational structure should be adjusted immediately because employee interactions tend to be no longer tiered. Employees can interact with other employees laterally, with all employees at various levels of position. Old work processes that tend to be physical and manual immediately adjusted to the digital work system. Office attendance hours, for example, should be changed immediately because the output base and physical presence in the office in many jobs no longer mean much. Likewise, other staffing systems also need to make adjustments more integrated into a digital basis.

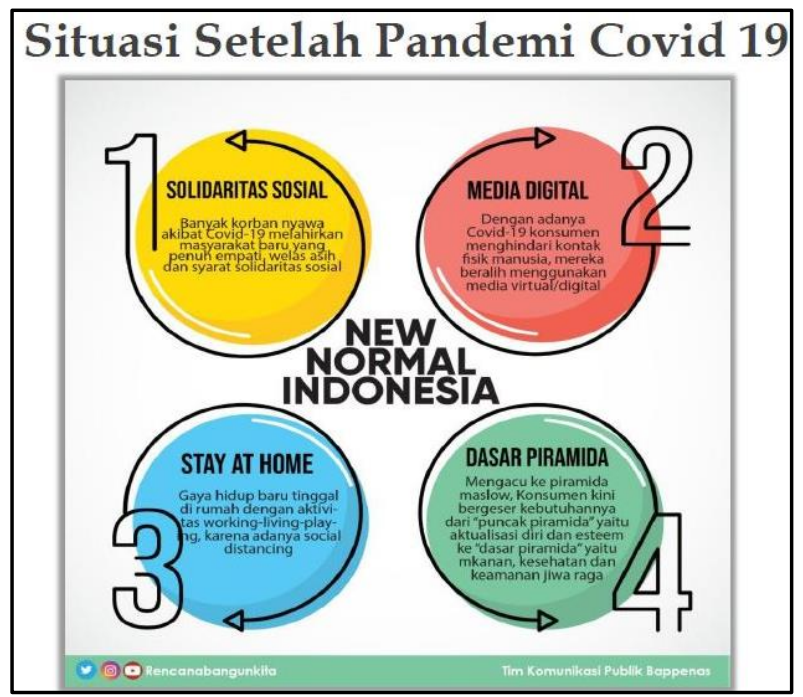

Figure 2 - New normal Indonesia (Wantiknas, 2020)

The 14th edition of the National ICT Council (Wantiknas) Discussion was held by the Ministry of National Development Planning of the Republic of Indonesia / National Development Planning Agency; with the theme of the discussion "Strategic Steps of Digital Transformation as the Fundamentals of New Normal Conditions" resulted in one of them are four points in Figure 2.

Based on Mobile Marketing Association data (MMA, 2020) it can be concluded that three things that were done by the community during \#Dirumahaja [\#stay@home] include an increase in television utilization, increased access to digital content, and an increase in self-competence. Changes in the increasingly 
digital lifestyle are predicted to continue when new normal conditions occur. The discussion has also explained four conditions that would happen in the new normalcy in Indonesia. Increasing social solidarity is encouraged by the large number of victims of COVID-19, the use of digital media, activities at home, and changes in the base of the community pyramid that previously focused on selfactualization will now be more directed to the foundation of the pyramid such as health and education.

For this reason, multi-stakeholder collaboration is needed so that the good culture carried out by the community during the COVID-19 pandemic can continue in the new normal state. The discussion produced a recommendation for a strategic step for digital transformation consisting of:

1. Ensuring the availability and quality of internet network infrastructure and electricity supply is maintained

2. Strengthening local applications supporting long-distance communication between Government agencies, especially in the aspect of enhancing cybersecurity

3. Optimizing the use of ICTs to support community activities in the fields of health, education, business, etc.

\section{Educational sector}

The COVID-19 emergency period which required that all teachers and students learn from their homes did not merely change location and learning methods, such as distance learning (Budi et al., 2020; Hashim et al., 2020). More significant than that, COVID-19 has encouraged many parties to make changes in the world of education in Indonesia in just a matter of months.

The Ministry of Education and Culture (MOEC) has made various learning adjustments during the pandemic. One of them encourages teachers not to focus on pursuing curriculum targets only during emergencies but also equips students with life skills that are loaded with values of character reinforcement. These adjustments are contained in Circular Letter No. 2 of 2020 concerning Prevention and Management of COVID-19 within the MOEC, and Circular Letter No. 3 of 2020 concerning Prevention of COVID-19 in the Education Unit. The MOEC encourages teachers not to complete all the material in the curriculum.

Meanwhile, in the capital city of DKI Jakarta, the school plan will be reopened on July 13, 2020. The DKI Jakarta Education Agency plans to restart teaching and learning activities in schools to coincide with the start of the new school year $2020 / 2021$. The plan was prepared by considering the implementation of largescale social restrictions (PSBB) to prevent COVID-19 transmission. The first day of school is arranged by considering policies, both central and local government. The Department of Education had compiled three learning schemes in schools that would be implemented in the 2020/2021 school year:

1. Only some schools are opened with all students studying at school. 
2. Only some schools are opened with some students studying at school.

3. All schools open with some students studying at home.

\section{Economic sector}

The Ministry of State-Owned Enterprises (BUMN) released the issuance of Circular Number: S-336 / MBU / 05/2020 Responding to the several circular SOEs from various sectors have prepared some new normal scenarios with their respective versions, based on the capacity and activities of the company (Koran Sindo, 2020). Then, from these variables emerged two aspects, namely the certainty of vaccine discovery and community behavior related to the COVID-19 pandemic. Based on these two aspects, four scenarios are formulated. In the first scenario, the death zone translates to a virus spreading rapidly where vaccines have not yet been found, and the medical care system is unable to cope with patients who are exceeding capacity. Medium community behavior is very ignorant of the safety and health protocol (Indartono et al., 2020).

The second scenario is the new normal. It was explained as the condition of the virus still existed, and the vaccine had not yet been found. As for the public behavior towards safety and health protocols, the spread of COVID-19 is slowing down, so the hospital care system can handle the number of patients well. Thus, the number of people who die is small, and businesses will look for new ways, new products, and new solutions that people need in living life in a world with new civilizations and cultures. The understanding of new normal does not mean returning to normal conditions before.

The third scenario, called Donkeyman, is that a vaccine condition is found and medical treatment can overcome or treat a COVID-19 patient. However, people's behavior does not care about the safety and health aspects again. The impact, the hospital remains crowded, although the fatality due to COVID-19 is not high. The fourth scenario, concerning longer life hope, vaccines are found, and the medical treatment system can treat or treat COVID-19 patients. Virtual and remote work has become a habit of society where digital transformation occurs massively, and productivity increases significantly.

\section{The Pros of the concept of "New Normal"}

The team for the acceleration of COVID-19 handling signed that the new normal is a change in behavior to keep running normal activities (Indartono et al., 2020). This update, however, is combined with the introduction of health protocols to avoid transmission of COVID-19. 


\section{The application of health protocols}

The main principle of the new normal is to adjust to the lifestyle. Health protocols become the rules mentioned in the implementation of new normal, namely by maintaining social distance by reducing physical contact with others. People will live a new normal life until a vaccine is found, which can be used to ward off the Coronavirus. This move is to coordinate life and new behavior when a pandemic is detected, which will then be carried out in the future before a COVID-19 vaccine is found. Experts believe the Corona vaccine, and world health experts will be available in 2021 . That is, new normal that must be lived by the community must be carried out at least until next year, maybe even more. Indonesian government invited to live in peace with the normal New COVID-19 eventually became a condition that must be faced by the community to coexist with the threat of this new Coronavirus.

Indeed, Indonesian President Jokowi said that it was time for the people to make peace with COVID-19. "That is, until the discovery of an effective vaccine, we must live in peace with COVID-19 for some time to come" (Kompas.Tv, 2020). As long as the plague still exists, he also requested that the community also continue to comply with health protocols.

New normal life is part of each country's exit strategy in dealing with the Coronavirus pandemic (Carr, 2020; Clark, 2020). The main strategy suggested by the World Health Organization (WHO) are testing, tracing, treating, and isolating (WHO, 2020). Regarding the policy easing by several countries, WHO mentioned many things that need attention due to the COVID-19 pandemic. Among other things, educate, involve, and empower people to live under new normal is recommended (Zeegen et al., 2020).

\section{New normal application in Indonesia}

New normal life was part of a strategy that was implemented before a vaccine or cure for the Coronavirus was discovered. "Restricting the number of crowds, limiting the distance, having to wear masks everywhere, and can be screened for temperature in every office or mall or school," (Budiman via Kompas.tv, 2020). Accordingly, business travel or personal travel should be limited only to circumstances that really matter. Children who have cough or flu are banned from school, or office workers who have the flu are also prohibited from entering the office. In public transportation, the number of passengers per vehicle (bus or busway) or train cars must be regulated. The government needs to educate and enforce new normal life rules on all aspects of people's lives as long as the corona vaccine has not been found.

\section{The Cons of the concept of "New Normal"}

"New Normal" is just the West's attempt to deceive the world over the evil character of their civilization, even though the death knell has sounded. Signs of death were 
evident in the condition of the United States (Hendreen, 2020), which became the heart of Western civilization.

Meanwhile, the bad character of the civilization of capitalism is reflected in its failure to overcome the COVID-19 pandemic, which has exacerbated chronic recession. That is, new normal is not just a life with some health protocols, but rather the life of the world in the civilization of capitalism which has a destructive character during the COVID-19 pandemic which was allowed to wreak havoc due to the pressure of the worst recession in history (Walton, 2020). As a result, the suffering of the world will deepen.

The concept of 'new normal life' and its relationship with several bad characters of civilization are hazardous for human life (Latief, 2020). On the other hand, the noble character of Islamic society in Indonesia and the world today requires its presence. The establishment of Western civilization based on the separation of religion from life, as well as its description of life as mere benefits, are two things that make Western civilization characteristically despicable, namely colonialism or imperialism.

Meanwhile, the United Nations (UN) institution which was initially in the form of an International Family only exists for the interests of the West and its civilization that does not want the existence of Islamic culture. Because the UN has launched the concept of 'new normal' as a formula and road map for the solution to today's world problems, loaded on its website through an article dated April 27, 2020, titled "A New Normal: UN lays out a roadmap to lift economies and save jobs after COVID-19" (UN, 2020). It was stated, the 'normal conditions' will never return, so the government must act to create a new economy and more jobs. In fact, 'new normal' has been established by the United Nations as a world framework and promoted a new, better life.

The United Nations framework responds directly to socio-economic issues as a result of COVID-19: Joint responsibility, urgent action for people in need, global solidarity, calling for the protection of jobs, businesses, and livelihoods to drive a safe community and economic recovery. As soon as possible in a sustainable, gender-equitable, and carbon-neutral manner - this is better than the 'normal'. In line with the functions of the United Nations, the World Health Organization (WHO), the UN under the bow in the field of health, has provided official support through May 15, 2020, News Release titled "Local epidemiology should be focused on 'new normal action' COVID-19 world". It stated, 'In the midst of increasing COVID-19 cases while countries in the WHO Southeast Asia region are gradually loosening lockdown, WHO today said that a careful assessment of the local epidemiology should guide action in combating the virus in the future come (WHO, 2020).

It is important to note, some WHO warnings cannot be regarded as reducing support for the "new normal" concept. Additionally, the principles that should be used as a guide in the transition to the "new normal", which was proclaimed by WHO 
on their page. Because the fact is, no country currently actually carries out these suggestions. As stated in suggestion 1: "Evidence (scientific) shows controlled COVID-19 transmission"; and advice 2: "Capacity of public health and health systems including hospitals is adequate for identification, isolation, testing, trace contact, and quarantine." This impossibility is up to the USA which is considered to have the best health system based on commercial insurance and also Italy which is considered to have the best health system in the world with compulsory health insurance based.

In addition, being behind Western civilization has become the WHO working principle. This can be seen from the content of Western civilization values in the International Health Regulation (IHR) (2005), which was used by WHO as a reference for overcoming the epidemic. Specifically, article 3 point 1: These Regulations shall be applied in full respect of the dignity, human rights, and fundamental freedoms of individuals (WHO, 2020).

\section{"New Normal", Poor Appreciation of Science}

Furthermore, the character of Western civilization that is no less low and dangerous is the insufficient appreciation of science, especially revelation. The logical consequence of the existence of Western civilization based on the middle way, not the truth, is in the form of separation of religion from life. Western civilization stands on the break of religion from life (Syafri, 2020). Ignorance of the truth of science also appears in the "new normal". This has made experts' concerns mount, especially health experts. Fauci (2020) opposed Trump's move to reopen schools and the economy when the outbreak was raging, and stated too many state governors, "There is a real risk that you will trigger an outbreak that you may not be able to control".

He also asserted, "We don't know everything about the virus, and we really better be pretty careful, especially when it comes to children." Whereas treatment and vaccines are no guarantees, as he stated, "The idea of having treatments available or a vaccine to facilitate the re-entry of students into the fall term would be something that would be a bit of a bridge too far." care and vaccines to facilitate students returning to school in the fall are too far a settlement). To the American people who are wondering when their lives are back to normal, he (Fauci) advised, "You have to be realistic and understand that it is not you who makes the timeline, the virus makes the timeline" (Washington Post).

This means that the epidemiological calendar timeline (the condition of the virus that causes the pandemic) should be the basis for when life activities can return to normal, not economic, and this requires scientific data. At the same time, the scientific data itself has not shown the COVID-19 curve in the world or in Indonesia. It has not seen any incline yet. Even in several countries, the upward sloping curve indicates a second pandemic wave. 
In Indonesia, some health experts have spoken. In particular, looking at epidemiological curves that are not sloping, they have not yet even peaked. But the government has created a timeline for economic activity. Indonesian Doctors Association (IDI) released that now is too fast to take new normal steps. To enter the new normal, the government must have data-based indicators and criteria for handling corona medically and epidemiologically (Kompas.tv, 2020). The Chairman of IDI Surabaya also said that he did not yet know when the corona would end. But if the "new normal" protocol is implemented, there is one homework assignment (Detik, 2020). Meanwhile, there is no guarantee that a health protocol will protect the public from an outbreak of a raging epidemic.

It is starting from the subordinate role of the state and public compliance, to the issue of health protocol standards. Because, to this day, knowledge about SARS Cov2 is still minimal, so it isn't easy to make genuinely standard health protocols. On the other hand, there is no guarantee that anyone, including those under 45 years of age has good immunity against COVID-19. These are the three bad characteristics of the civilization of capitalism which also characterize the concept of "new normal". So, the "new normal" is none other than the civilization of capitalism with its bad character that allows a pandemic to spread (herd immunity), to achieve material value (free from recessionary pressure).

That is, the state increasingly does not care about the health and safety of the soul of the people. At the same time, everyone must struggle even more challenging to take care of their lives, dealing with corporate greed and domination agendas facilitated by the state amid the ferocity of the plague. More than that, the existence of Islamic civilization based on Islamic creed makes it the only civilization that fits the nature of the children. Besides, because he describes life as an activity that runs in accordance with the commands and prohibitions of God and the meaning of happiness in the form of Allah, all of this necessitates that in Islamic civilization the harmonious material, spiritual, humanitarian, and moral values are realized.

On the other hand, nullifies the aspects of sovereignty along with the realization of a proper state function. Thus, humans are in a noble position amid the rapid advances in science and technology (Meiryani et al., 2020). The sweet fruit of the harmony of Islamic civilization with the truth of science. In Quran (17: 70), Allah emphasizes, "We have glorified the children of Adam." Not just a concept, Islamic civilization, with its noble character as an expression of the welfare of all nature, has truly been tested for decades and in two-thirds of the world. This has all been carved by the golden ink of historical civilization.

Today, with its perfect character, Islamic civilization is the only hope of the world-liberator from the protracted COVID-19 pandemic. Also, the liberator of the world from the hegemony agenda: both in the East by China and its allies, and in the West by the US and its allies. Next with international institutions such as WHO, UN, 
WB, IMF, and the world's giant corporations that make health and human lives as objects of domination.

\section{"New Normal", Only Material Value Is Recognized}

In addition to the character of imperialism, the nature of capitalism's civilization that is no less bad and dangerous is to acknowledge material value only. Therefore, it will not be found in Western society, moral values, or spiritual values, or human values, except material costs. Thus, the economic aspect which only discusses the material elements and benefits in its financial system becomes the focus and even addresses the health and human lives. Health itself is nothing more than services that must be commercialized. This can be seen in the concept of "new normal" or "new normal life". For the sake of the desire to achieve material value, the ruling regime is disengaged from overcoming the COVID-19 pandemic that is raging. Despite that, the health and lives of billions of people are at stake.

At the same time, they focused on his function as a corporate servant and implementer of the Western hegemony agenda, especially the economy. Indeed, the UN emphasized that, both during and after the crisis, everything has to be done with a strong emphasis on creating a more equitable, inclusive, and prosperous economy and society that is more robust in the face of a pandemic, climate change, and other global challenges (UN, 2020).

Meanwhile, economic development and a more equal, inclusive, and sustainable society, which has so far been practiced are only putting forward material values so that there is nothing left but the misery of humanity. The material value that dominates the new normal concept is also apparent from the five pillars of the UN framework for the success of the "new normal". The five pillars, namely: "(1) Primary health, including the protection of health services and systems (easy access to essential health services and strengthening of health systems; (2) social protection and basic services; (3) economic response and recovery; (4) response macroeconomics and collaboration, and (5) social cohesion and community resilience" (UN, 2020).

The UN framework is an inseparable part of Western civilization. So, there is no doubt that material values and business aspects are the main, including the health aspects. Therefore, although health is positioned first, it is not for the health of the salvation of the souls of humanity, but for material value and industrialization as we have seen, such as the fact of the health system of capitalism.

\section{'We have straight normal forever' rather than New Normal}

Indonesian former chairman of the council of public consultations, Amien Rais, disagree with the concept of new normal. He attacks the government through the term 'new normal' about the COVID-19 pandemic. Accordingly, the term 'New 
Normal' is not appropriate to be used in combating the Coronavirus today. He also suggested using the term 'We have straight normal forever', or we should continue normally forever. Because according to him, what are normal are usually standard, fixed patterns through absolute references.

He provides some evidence from some scientists who, according to him, had given the opinion that new normal is a misdirected term. He claimed to believe in that opinion. "Well, fortunately, there is a scientist who reminds us that the words new normal are misleading, misdirected, and there is a deception". Accordingly, the scientists stated that what happened was to destroy normal forever. He called normal, which usually is to have standards, norms, and regular patterns that refer to a reference.

To support his argument, he proposed a warrant, "What happened was a worsening situation, whether it was climate change or global warming, destruction everywhere, rising sea levels that were increasingly unbearable. Therefore, Ladies and Gentlemen, they proposed not to use this again; this could trick us. "Our slogans consume us, and then whatever is considered normal,". Then, he claimed to understand that the top brass in Indonesia wanted a new normal after the spread of the Coronavirus began to slow. Amien still agrees with the new normal, such as civil servants who continue to work with masks, keep their distance, and divide working time at home and office. "But if then widespread unemployment is new normal, riots in villages and cities due to hunger stomach new normal, added debt continues to be normal, our country's economy is new and more normal, that's what I think has gone too far. "So, let's be an intelligent nation, the leaders must also be smarter, sorry, because we are really in a weighty atmosphere. Don't be entertained by the new normal, normal, normal, right?"

\section{CONCLUSION}

The "New Normal" policy has been implemented in Indonesia, and it raises the pros and cons described above. However, the new normal causes more negativity effects, striving to be normal forever is better than applying the new normal. The primer information from WHO, policymaker, and researchers contributed to the discussion. Health protocols become the rules mentioned in the implementation of a new normal, namely by reducing physical contact with others. But the new normal policy is no less low and dangerous, is the insufficient appreciation of science, especially revelation. Additionally, the concept of new normal has not valued except just taking material and economic benefits. 
Volume 4 Number 3 March 2021

\section{REFERENCES}

Abidah, A., Hidaayatullaah, H. N., Simamora, R. M., Fehabutar, D., \& Mutakinati, L. (2020). The Impact of COVID-19 to Indonesian Education and Its Relation to the Philosophy of "Merdeka Belajar". Studies in Philosophy of Science and Education, 1(1), 38-49. https://doi.org/10.46627/sipose.v1i1.9

Belliappa, J. L. (2020). Extending feminist pedagogy in conferences: Inspiration from theatre of the oppressed. Gender and Education, 32(1), 101-114.

Benjamin, S., Dillette, A., \& Alderman, D. H. (2020). "We can't return to normal”: Committing to tourism equity in the post-pandemic age. Tourism Geographies, (Article in press).

Budi, H. S., Ludjen, J. S. M., Aula, A. C., Prathama, F. A., Maulana, R., Siswoyo, L. A. H., \& Prihantono, A. S. (2020). Distance learning (DL) strategies to fight coronavirus (COVID-19) pandemic at higher education in Indonesia. International Journal of Psychosocial Rehabilitation, 24(7), 8777-8782.

Carr, E. (2020). New Normal Terminology (Editorial). Clinical Journal Of Oncology Nursing, 24(3), 223.

Chen, R. C., Tan, T. T., \& Chan, L. P. (2020). Adapting to a new normal? 5 key operational principles for a radiology service facing the COVID-19 pandemic. European Radiology, (Article in press).

Clark, K. (2020). Innovation in a post-COVID 'new normal' (Editorial). The Veterinary record, 186(16), 511.

Covid19.go.id. (2020). Situasi Virus Corona. https://www.COVID19.go.id/situasivirus-corona/

Detik. (2020). IDI Surabaya sebut new normal belum dapat diterapkan di Jawa Timur. https://m.detik.com/news/berita-jawa-timur-/d-5022741/idisurabaya-sebut-new-normal-belum-tepat-diterapkan-di-jawa-timur

Djalante, R., Nurhidayah, L., Lassa, J., Minh, H. V., Mahendradhata, Y., Phuong, N. T. N., Trias, A. P. L., Myoe, M. A., Djalante, S., \& Sinapoy, M. S. (2020). The ASEAN's Responses to COVID-19: A Policy Sciences Analysis http://dx.doi.org/10.2139/ssrn.3595012

Erduran, S. Jimenez-Aleixandre, \& Pilar, M. (2007). Argumentation in Science Education: Perspectives from Classroom-Based Research. New York: Springer.

Fauci. (2020). Donald Trump presses for schools to reopen makes dig. https://www.financialexpress.com/world-news/donald-trump-pressesfor-schools-to-reopen-makes-dig-at-anthony-fauci-1958512/

Fleming, G. (2020, February 11). 5 steps to writing a position paper. https://www.thoughtco.com/how-to-write-a-position-paper-1857251

Hashim, S., Masek, A., Abdullah, N. S., Paimin, A. N., \& Muda, W. H. N. W. (2020). Students' intention to share information via social media: A case study of COVID-19 pandemic. Indonesian Journal of Science and Technology, 5(2), 6170 . 
Hendreen, J. (2020). US sees biggest food price rises in 46 years. https://www.aljazeera.com/news/2020/05/sees-biggest-food-price-rises46-years-200516140104954.html

Indartono, S., Asaduddin, A. H., \& Soraya, Y. (2020). The Indonesian citizen behavior in facing COVID-19. International Journal of Psychosocial Rehabilitation, 24(9), 335-344.

Kompas.Tv. (2020). Sorotan Indonesia bersiap menuju new normal. https://www.kompas.tv/article/82018/sorotan-indonesia-bersiapmenuju-new-normal.

Koran Sindo. (2020). Menuju New Normal: Seperti apakah itu?. https://nasional.sindonews.com/read/37714/16/menuju-new-normalseperti-apakah-itu-1589911523

Latief, K. P. (2020). Ini dia ketentuan New Normal WHO agar bisa berdampingan dengan Virus Corona. Retrieved 25/05/2020 from https://www.harapanrakyat.com/2020/05/ketentuan-new-normal-who/

Meiryani, Siagian, P., Lusianah, \& Lesmana, T. (2020). Technology's role to avoid the spread of COVID-19. International Journal of Psychosocial Rehabilitation, 24(7), 9902-9909.

Mma. (2020). COVID-19 impact: What's happening in the TV \& smartphone landscape. https://www.mmaglobal.com/node/34565

Razzak, A. (2020). Paulo Freire's critical and dialogic pedagogy and its implications for the Bahraini educational context. Educational Philosophy and Theory, (Article in press). https://doi.org/10.1080/00131857.2020.1716731

Republika. (2020). 5 Inovasi Digital Biar Bisnis Survive Saat Pandemi COVID-19. https://republika.co.id/berita/q9g4nc7417000/5-inovasi-digital-biarbisnis-survive-saat-pandemi-COVID19

Suprapto, N. (2016). What should educational reform in Indonesia look like? Learning from the PISA science scores of East-Asian countries and Singapore. Asia-Pacific Forum on Science Learning and Teaching, 17(2), 16.

Suprapto, N., Liu, W. Y., \& Ku, C. H. (2017). The implementation of multiple intelligence in (Science) classroom: From empirical into critical | [Daugialypio intelekto teorijos taikymas (Tiksliųjų mokslų) pamokose: nuo empirinio iki kritinio požiūrio]. Pedagogika, 126(2), 214-227.

Syafri, R. (2020). Pandemi COVID-19, "New Normal", dan kebutuhan dunia terhadap peradaban islam. http://www.muslimahnews.com/2020/05/26/COVID-19new-normal-peradaban-islam/

UN. (2020). A new normal: UN lays out roadmap to lift economies and save jobs after COVID-19. https://www.un.org/africarenewal/news/coronavirus/newnormal-un-lays-out-roadmap-lift-economies-and-save-jobs-after-COVID-19

Walton, G. (2020). COVID-19: The new normal for midwives, women and families. Midwifery, (Article in press), Article number 102736. 
Wantiknas. (2020). Sambut Fase New Normal, Diskusi Wantiknas ke-14 Dorong Transformasi Digital. https://pusdatin.kemdikbud.go.id/sambut-fase-newnormal-diskusi-wantiknas-ke-14-dorong-transformasi-digital/

Washington Post. Coronavirus (2020). https://www.washingtonpost.com/nation/2020/03/26/coronavirus-cnnfauci/

WHO. (2020). Local epidemiology should guide focused action in new normal COVID19 world. https://www.who.int/southeastasia/news/detail/15-05-2020local-epidemiology-should-guide-focused-action-in-new-normal-COVID-19world.

Zeegen, E. N., Yates, A. J., \& Jevsevar, D. S. (2020). After the COVID-19 pandemic: returning to Normalcy or returning to a new normal?. The Journal of arthroplasty, 35(7), S37-S41. 